УДК $378.147-056.45$

DOI:

Алла Ревть, кандидат педагогічних наук, дочент кафедри загальної педагогіки та дошкільної освіти

Дрогобицького державного педагогічного університету імені Івана Франка Ігор Гриник, кандидат педагогічних наук, доцент кафедри сочіальної педагогіки та корекційної освіти Дрогобицького державного педагогічного університету імені Івана Франка

\title{
ПСИХОЛОГО-ПЕДАГОГІЧНІ ЗАСАДИ РОБОТИ 3 ОБДАРОВАНОЮ СТУДЕНТСЬКОЮ МОЛОДДЮ
}

У статті здійснено комплексний аналіз вітчизняних $і$ зарубіжних напрацювань з питань обдарованості студентської молоді; розкрито змістове наповнення провідних понять проблеми. Висвітлено систематизовано ознаки, види, функиї та узагальнено якості обдарованої особистості. Проаналізовано психолого-педагогічні підходи до роботи з обдарованою молоддю.

Досліджено й визначено зміст, форми та методи роботи з обдарованими студентами у закладах вищої освіти в Україні. Охарактеризовано соціальні умови розв'язання проблем особистісної соціальноі самореалізачї і професійного самовизначення обдарованих студентів у нових соціально-економічних умовах.

Робота з обдарованими студентами вимагає належної змістової наповненості занять, зорієнтованої на новизну інформації та різноманітні види пошукової аналітичної, розвивальної, творчої діяльності.

Ключові слова: обдарованість; студентська молодь; творча особистість; самореалізачія; творчі здібності.

Jim. 9.

Alla Revt, Ph.D.(Pedagogy), Associate Professor of the General Pedagogy and Preschool Education Department, Drohobych Ivan Franko State Pedagogical University

Ihor Hrynyk, Ph.D.(Pedagogy), Associate Professor of the Social Pedagogy and Correctional Education Department, Drohobych Ivan Franko State Pedagogical University

\section{PSYCHOLOGICALAND PEDAGOGICAL PRINCIPLES OF WORK WITH GIFTED STUDENTS}

One of the most important resources of the society is its intellectual potential, represented by a community of people who have found their place in life, realized their own creative and professional capabilities, intellectual and organization abilities. There is a growing need for people who have a non-standard mindset, are able to set and solve new complex tasks related to creating the future. They are the main driver of progress in all spheres of the society and the state.

The article provides a comprehensive analysis of domestic and foreign researches of the talents of student youth, the semantic content of the leading concepts of the problem is revealed. The features, types, functions and qualities of the gifted person are covered and systematized. Psychological and pedagogical approaches to work with gifted youth are analyzed.

The content, forms and methods of work with gifted higher education students in Ukraine are studied and determined. Social conditions for solving problems of personal social self-realization as well as professional selfdetermination of gifted students in the new socio-economic conditions are characterized.

The work with gifted students requires proper content of the lessons, focused on the novelty of information and various types of exploratory analytical, developmental and creative activities. In a higher educational institution, the forms of organization of the educational process are traditionally a lecture, seminar, laboratory workshop, individual and group consultations, colloquia, business games, educational conferences, etc.

However, among the methods of teaching gifted students independent work should dominate, exploratory and research approaches to the acquisition of knowledge, skills and abilities. Control over their studies should stimulate in-depth study, systematization, classification of educational material, transfer of knowledge to new situations, the development of their creative abilities. It is important to teach students to understand the situation, analyze it, identify the leading ideas that underline the creative search, develop constructive schemes and options for practical solutions.

Keywords: giftedness; student youth; creative personality; self-realization; creative abilities.

$\Pi$ остановка проблеми. За умов сучасного стану розвитку українського суспільства фухуу напрямі європейської інтеграції, особлива увага повинна бути скерована на формування у майбутніх кваліфікованих фахівців різних сфер потреби у постійному прогресі, 
професійному рості та розвиткові, творчій інтерпретації власної діяльності, активному використанні надбань науки та техніки. Зусилля закладів вищої освіти мають бути скеровані, насамперед, на тих студентів, які володіють високим інтелектуальним потенціалом та значущими технічними, творчими чи лідерськими здібностями, що проявляються як у теоретичному, так і практичному навчанні.

Заклади вищої освіти у процесі своєї діяльності намагаються вибудувати певну стратегію взаємодії із такими студентами: розвивати у них творче мислення, визначати ще з моменту вступу до ЗВО специфічні академічні здібності та сприяти їх розвиткові.

Деякі як вітчизняні, так і зарубіжні науковці намагалися сформулювати власне визначення поняття обдарованості [2; 5; 7]. На думку вчених, обдарованість - це загальні здібності, що обумовлюють широту можливостей людини, рівень і своєрідність іiі діяльності, розумовий потенціал, цілісну індивідуальну характеристику пізнавальних можливостей і здібностей до навчання. Обдарованість передбачає наявність сукупності задатків, природних даних, тобто це характеристика міри вираження і своєрідності природних передумов здібностей.

На думку В. Моляко, обдарованість є однією 3 найважливіших вищих психічних підсистем упорядкування системи людина - світ. Вона нерозривно пов'язана з усіма іншими психічними функціями людини, з її свідомістю, підсвідомістю, загальними установками і диспозиціями, особистісними структурами, емоційною сферою і т.д. [5].

Так, наприклад, Р. Семенова інтегрувального якістю обдарованої особистості пропонує вважати креативний потенціал, що характеризує іiі здатність до розвитку, створення нового, не зупиняючись на досягнутому рівні актуалізованих можливостей (критерій обдарованості вченою розглядається рівень сформованості внутрішньосуб'єктних психологічних механізмів, які можуть виступати основою креативної поведінки в тій чи іншій сфері діяльності (навчальній, науковій, художній, технічній і т.д.) [7, 37].

Дж. Гілфорд пов'язував найхарактернішу ознаку творчо обдарованої людини 3 їі дивергентним мисленням (швидкість; гнучкість; оригінальність; точність $[2,433])$ як основою креативності. Він розробив систему уніфікованого творчого процесу, наголошуючи, що творчість характерна не лише для геніїв і талантів, а $є$ властивістю звичайної людини, і структура цієї діяльності принципово однакова на всіх рівнях.
Головною ознакою творчих здібностей особистості вчений вважав здатність бачити (відчувати) проблему (недосяжну мету, нездійсненне бажання, реальні суперечності тощо).

Аналіз наукових підходів багатьох дослідників проблеми обдарованості, зокрема Ю. Гільбуха, О. Кульчицької, А. Луки, О. Матюшкіна, В. Моляко та інших, дав змогу В. Онацькому $[6,53]$ також визначити три провідні компоненти, які охоплює обдарованість: задатки, нахили, пізнавальні здібності і навички; емоційно-вольова сфера.

Мета статті - окреслити особливості психолого-педагогічної роботи з обдарованою студентською молоддю у закладах вищої освіти України.

Виклад основного матеріалу дослідження 3 повним обгрунтуанням отриманих наукових результатів. На думку сучасних українських дослідників, проблема виявлення та навчання обдарованої молоді головним чином $\epsilon$ психолого-педагогічною, що потребує реалізації нових підходів до організації їх навчання, розвитку й побудови нового змісту освіти.

Однією $з$ характерних особливостей творчо обдарованої людини є те, що власні здібності оцінюються нею не як статична, а як динамічна характеристика. Усвідомлення можливостей розвитку власних здібностей - один із ключових моментів у становленні творчо обдарованої особистості. Вчені, які досліджують проблеми творчої особистості, її творчої обдарованості, намагаються встановити вихідний критерій, за яким можна виявити зміст означеного феномену.

Так, Е. Лодзіньська [4] зазначає, що у практиці навчання і виховання молоді ця проблема набуває дидактичного і методичного аспектів, оскільки вимагає психолого-педагогічного обгрунтування технологій навчання і виховання обдарованої молоді, а також побудови відповідних методичних систем, що враховували б особливості психічного розвитку і своєрідність мислення таких молодих людей. Отже, авторка впевнена, що соціально значима практична потреба у творчо мислячих людях насамперед вимагає відповідних педагогічних досліджень, які розкривали б особливості побудови освітнього процесу при роботі з обдарованою молоддю, а також давали б практичні поради і методичні рекомендації педагогам у питаннях пошуку, навчання i виховання обдарованої молоді.

Отже, аналіз вищенаведених підходів до характеристик якостей обдарованої особистості допоміг нам узагальнити їх та запропонувати своє бачення психолого-педагогічного портрету 
обдарованого студента, розробити відповідну структуру якостей (показників):

1. Світоглядні - чітка філософська позиція, широкий світогляд та кругозір, орієнтація на норми моралі, загальнолюдські й духовні цінності.

2. Інтелектуально-творчі - високий рівень академічних знань, їх різнобічність, спостережливість, розвинена пам'ять, наявність художньо-образного способу мислення, творча уява, інтуїція, нестандартне мислення, асоціативність.

3. Мотиваційні - потреба у творчості, самореалізації, у високих досягненнях.

4. Емоційно-вольові якості - емоційність, комунікабельність, вольові якості-самостійність, ініціативність, наполегливість.

5. Практично-процесуальні - сформованість навичок літературно-мистецької діяльності, здатність до планування та самоорганізації роботи, навички аналізу і самоаналізу.

Така характеристика особистості студента дає змогу оптимізувати процес практичної роботи щодо розвитку обдарованої особистості, оскільки ми розглядаємо соціально-педагогічну роботу як процес, що забезпечує створення соціальнопедагогічних умов для розвитку цих якостей (показників), а розвиток обдарованості студента - як цілеспрямований соціально-виховний процес розвитку світоглядних показників, інтелектуальнотворчих, мотиваційних, емоційно-вольових якостей, практично-процесуальних умінь і навичок студента.

С. Фурдуй виділяє такі напрями роботи 3 обдарованою студентською молоддю $[9,105]$ :

Координаційний. Здійснюється організація роботи зі створення і керівництва діяльністю експериментальних майданчиків по роботі 3 обдарованими студентами, організація та проведення масових заходів, олімпіад і науковопрактичних конференцій. Відбувається вдосконалення нормативно-правової бази, відстеження дотримання чинного законодавства. Здійснюється інформування щодо правової бази роботи з обдарованою студентською молоддю. Забезпечується координація діяльності з реалізації цільових програм по роботі з обдарованою молоддю.

Інформаційний. Запроваджена консультаційна підтримка, що передбачає інформування молоді та педагогів 3 питань, пов'язаних із виявленням, розвитком і підтримкою обдарованої молоді. Привертається підготовка фахівців за напрямом роботи з обдарованою молоддю. Залучається увага громадськості, засобів масової інформації: публікації в періодиці, позначення проблем обдарованої молоді на відкритих конференціях, семінарах, використання мережі Інтернет для поширення інформації про специфіку навчання обдарованої молоді, методики, особливості психології і т. д.

Діагностичний. Створюються науководослідні школи з різних навчальних дисциплін, інтелектуальні клуби, запроваджується дослідницька діяльність, проводяться олімпіади, конкурси, фестивалі, науково-навчальні конференції задля виявлення критеріїв обдарованості.

Соиіально-педагогічний. Передбачає розробку та впровадження заходів щодо оптимізації організаційних умов освітнього процесу, що зі свого боку, вимагає виявлення відносин обдарованих студентів до тої чи тієї освітньої діяльності [9, 108].

Сочіально-психологічний супровід обдарованої студентської молоді передбачає: забезпечення соціального та психологічного здоров'я студентів, які навчаються за спеціальними програмами; створення системи психологічного супроводу педагогічного та навчального процесів; упровадження системи відстеження розвитку професійних та особистісних здібностей, закономірностей їх динаміки, побудови набору можливих індивідуальних траєкторій розвитку; надання обдарованій молоді своєчасної психологічної підтримки. Компоненти психологопедагогічного супроводу: соціально-психологічний моніторинг; тренінги; індивідуальні консультації для педагогів; корекційна робота; групові консультації для студентської молоді; соціальнопсихологічні, психолого-педагогічні практикуми; система семінарів і практикумів для викладачів.

Соиіально-виховний. Обдаровані студенти найбільш стійкі та віддані підсистемі університетського духу. Виховна робота, зокрема робота $з$ формування корпоративної культури, удосконалюється за рахунок активного залучення студентів до самоврядування, різних форм спортивно-масової, клубної роботи, участі в оглядах-конкурсах, КВК, фестивалях, науководослідній роботі та ін. В університеті створені структури управління виховною роботою на рівні закладу вищої освіти, факультетів і кафедр, діють органи студентського самоврядування. Розвивається матеріально-технічна база для проведення позанавчальної роботи. Відроджуються студентські проблемні групи; вдосконалюється створена система заохочення студентів за активну участь у громадському житті закладу вищої освіти.

Відповідна робота з обдарованими, здібними та талановитими студентами має здійснюватися за дотримання таких умов: взаємодії, взаєморозуміння, узгодженості діяльності усіх суб'єктів освітнього процесу. 
На нашу думку, реалізація студентом своєї обдарованості буде успішною не лише при забезпеченні ефективного психолого-педагогічного супроводу, а й за умови проведення ним передовсім, самодіагностики власної особистості, яка допоможе виявити, наскільки він володіє якостями, що створюють умови для стійкого творчого старту, успішної творчої реалізації.

Оцінюючи рівень сформованості показників обдарованості студентів і враховуючи здатність до адекватної самооцінки молодих людей цього віку, ми вважаємо за доцільне використати як додаткову експертну оцінку самооцінку студента.

Самооцінку рівня сформованості показників творчої обдарованості можна провести 3 допомогою тесту, розробленого Іриною Карповою, “Творча обдарованість студента” [3]. При розробці тесту, як вказує автор вона використала тест Н. Вишнякової та Р. Ткач “Креативність" $[1,44]$ та методику діагностики особистості на мотивацію до успіху Т. Елерса [8, 129], адаптовані до завдань нашого дослідження, в якому використані такі умовні позначенняіндекси: С - світоглядний критерій; IT інтелектуально-творчий критерій; М мотиваційний критерій; ЕВ - емоційно-вольовий критерій; ПП - практично-процесуальний критерій. Позначка в дужках означає індекс певного критерію (або показника), наприклад, С (ф) - світоглядний критерій (показник філософське сприйняття дійсності, або, скажімо IT (c) інтелектуально-творчий критерій (показник спостережливість) і т.д.

Отже, при проведенні самодіагностики студенти виявляють, настільки кожен із них володіє якостями критеріїв власної обдарованості (світоглядного, інтелектульно-творчого, мотиваційного, емоційно-вольового, практично-процесуального).

Відповідаючи на запитання тестів, студенти одночасно здійснюють самооцінювання прояву кожного показника, виставляючи собі до кожного запитання високий (B), середній (C) чи низький (Н) бал. Високий бал ставиться за умови постійного, частого, яскраво вираженого прояву того чи того критерію чи відповідного показника або постійного прояву психологічної реакції на певну ситуацію (- так, - постійно, -дуже часто); середній бал студент виставляє при ситуативному прояві певних критеріїв та відповідних показників обдарованості в поведінці чи діяльності (-інколи, -не завжди, частково тощо); низький бал отримує студент за умови відсутності чи мінімального прояву певних критеріїв, відповідних показників чи певної ситуації в діяльності студента (що відповідає оцінці - ні, -ніколи, -дуже рідко ).
На основі отриманих результатів студент здійснює підрахунки коефіцієнтів світоглядних, інтелектуально-творчих, мотиваційних, емоційновольових якостей, практично-процесуальних умінь і навичок, коефіцієнта творчої обдарованості. На основі формули підрахунку того чи того коефіцієнта (Кс, Кіт, Км, Кев, Кпп та Кто) студент зможе самостійно встановити рівень сформованості показників та вивести коефіцієнт власної творчої обдарованості. Якщо показник будь-якого коефіцієнта розміщений у діапазоні $0-0,33$ коефіцієнт обдарованості чи будь-якого критерію низький; у діапазоні 0,331-0,66 - коефіцієнт обдарованості чи конкретного критерію середній; в діапазоні 0,661-1 - коефіцієнт обдарованості чи конкретного критерію високий.

Вважаємо, що запропонована методика самодіагностики студентами рівня сформованості показників обдарованості дозволяє студентам оцінити критерії (та показники) власної обдарованості, які відповідають Я-реальному, так і Я-ідеальному та зробити відповідні підрахунки коефіцієнтів власної творчої обдарованості Яреального та Я-ідеального.

Результати самотестування, запропонованого I. Карповою доводять, що образ Я-реальний (тобто уявлення людини про себе в даний, конкретний момент) та образ Я-ідеальний (тобто уявлення людини про те, якою вона повинна бути, щоб відповідати суспільним нормам, моральноетичним цінностям, очікуванням навколишніх), як правило, не збігаються, отже, коефіцієнт Яідеального можна розглядати як ту мету творчої самореалізації, до якої прагне студент.

Таким чином, ідеальна уява про творчу обдарованість виконує функцію регулятора самооцінки і рефлексії, але при цьому слід мати на увазі, що у людей ідеальна уява про свої творчі можливості не збігаються з реальною, вона може бути завищеною чи заниженою. Водночас слід мати на увазі, що визначення коефіцієнтів творчої обдарованості образу Я-реального та образу Яідеального створює можливості орієнтира для студента та соціального педагога при визначенні рівня індивідуальної програми розвитку творчої обдарованості особистості.

На нашу думку, здійснений студентом аналіз результатів самотестування творчої обдарованості Я-реального допоможе йому визначити рівень розвитку кожного критерію та кожної якості його творчої особистості, проаналізувати, які 3 них гальмують творчу самореалізацію, а значить потребують особливого розвитку.

Висновки. Вважаємо, що у вивченні питання шляхів роботи з обдарованою молоддю варто 
звернути увагу на соціально-педагогічні та психологічні особливості обдарованих студентів. Своєчасним буде використання таких напрямів роботи 3 обдарованою молоддю, як: координаційний, інформаційний, діагностичний, соціально-педагогічний, психолого-педагогічний супровід обдарованої студентської молоді та соціально-виховний.

Таким чином, ефективна робота зі створення в університеті комплексу координаційних, інформаційних, діагностичних, психологопедагогічних, соціально-педагогічних, соціальновиховних умов забезпечує розкриття здібностей i самореалізацію студентів, дає змогу надати роботі з обдарованою молоддю системний практико-орієнтований характер.

\section{ЛІТЕРАТУРА}

1. Вишнякова Н. Ф., Ткач Р.В. Тест “Креативність”. Обдарована дитина. 1998. № 5-6. С. 44-49.

2. Гилфорд Дж. Три стороны интелекта. Психология мышления. Москва: Прогресс, 1969. C. 433-456.

3. Карпова І. Г. Соціально-педагогічні чинники виявлення творчого потенціалу студента у позанавчальній діяльності вищого навчального закладу. Соціалізація особистості : зб. наук. працьь / за заг. ред. проф. А. Й. Капської. Том ХХХІ. Київ: НПУ імені М.П. Драгоманова, 2008. С. 166-180.

4. Лодзінська Е. Особливості роботи вчителя 3 математично обдарованими учнями. Матеріали всеукраїнської конференції “Актуальні проблеми вивчення природничо-математичних дисциплін у загальноосвітніх нав-чальних закладах України". Київ: Київський університет імені Т.Шев-ченка, 1999. с. 104

5. Моляко В.О. Проблеми психології творчості та розробка підходу до вивчення обдарованості. Обдарована дитина. 2002. № 4. С. 19-25.

6. Онацький В.М. Академічна обдарованість та методи їі діагностики. Обдарована дитина. 2002. № 2. С. 53-56.

7. Психологічна діагностика обдарованості: Монографія / За редакцією Р.О. Семенової. Кіровоград, 2012. 172с.

8.РайгородскийД.Я.Практическаяпсиходиагностика. Методики и тесты. Москва: Издательский Дом Бахрах, 2002. 672 c.

9. Фурдуй С. Б. Соціальна робота: шляхи іiі реалізації в системі вищої освіти з обдарованою молоддю. Соиіальна робота в Україні: теорія і практика. 2016. №1-2. С. 102-111.

\section{REFERENCES}

1. Vyshniakova, N. F. \& Tkach, R.V. (1998). Test "Kreatyvnist" [Creativity Test]. A gifted child. No.56. pp. 44-49. [in Ukrainian].

2. Gilford Dzh. (1969). Tri storonyi intelekta [Three sides of intelligence]. Psychology of thinking. Moscov. pp. 433-456. [in Russian].

3. Karpova, I. H. (2008). Sotsialno-pedahohichni chynnyky vyiavlennia tvorchoho potentsialu studenta u pozanavchalnii diialnosti vyshchoho navchalnoho zakladu [Socio-pedagogical factors of identifying the creative potential of the student in extracurricular activities of higher education]. Socialization of the individual: Coll. of Science. Works. (Ed.). A. Y. Kapska. Vol. XXXI. Kyiv. pp. 166-180. [in Ukrainian].

4. Lodzinska, E. (1999). Osoblyvosti roboty vchytelia z matematychno obdarovanymy uchniamy [Features of the teacher's work with mathematically gifted students]. Materialy vseukrainskoi konferentsii “Aktualni problemy vyvchennia pryrodnycho-matematychnykh dystsyplin u zahalnoosvitnikh navchalnykh zakladakh Ukrainy" Proceedings of the All-Ukrainian Conference "the actual Problems of Studying Natural and Mathematical Disciplines in Secondary Schools of Ukraine". Kyiv, p.104. [in Ukrainian].

5. Moliako, V.O. (2002). Problemy psykholohii tvorchosti ta rozrobka pidkhodu do vyvchennia obdarovanosti [Problems of creativity psychology and development of an approach to the study of giftedness]. A gifted child. No.4. pp. 19-25. [in Ukrainian].

6. Onatskyi, V.M. (2002). Akademichna obdarovanist ta metody yii diahnostyky [Academic talent and methods of its diagnosis]. A gifted child. No. 2. pp. 53-56. [in Ukrainian].

7. Psykholohichna diahnostyka obdarovanosti: Monohrafiia [Psychological diagnosis of giftedness: Monograph]. (Ed.). R.O. Semenova. Kirovohrad, 2012. 172 p. [in Ukrainian].

8. Raihorodskyi, D. Ya. (2002). Prakticheskaya psihodiagnostika. Metodiki i testyi [Practical psychodiagnostics. Techniques and tests]. Moscov, 672 p. [in Ukrainian].

9. Furdui, S. B. (2016). Sotsialna robota: shliakhy yii realizatsii v systemi vyshchoi osvity z obdarovanoiu moloddiu [Social work: ways to implement it in the system of higher education with gifted youth]. Social work in Ukraine: the theory and practice. No.12. pp. 102-111. [in Ukrainian].

Стаття надійшла до редакції 03.02.2021

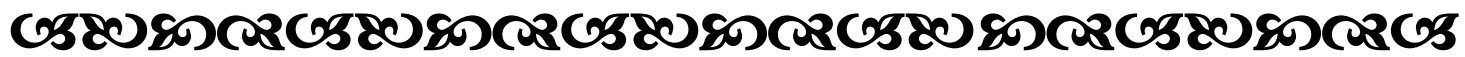

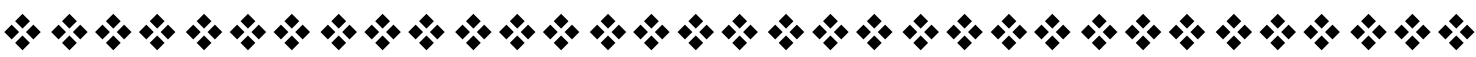

